\title{
What Tosi Abdur Razzaq Felt about Tahara I Function
}

\author{
Tosi Abdur Razzaq
}

October 6, 2019

\begin{abstract}
I felt the sentences when I read Thara's papers about Tahara $I$ function.
\end{abstract}

\section{Explanation}

I got a LINE message about Tahara $I$ function from Tahara who have studied something[1][2][3]. After I read his papers[4][5][6] and send massage-sentences written below to him.

\section{The Sentences}

まず、ひろきくんのしたいことを何度も文章を読んで、理解しようとしました。正しい解釈かそうでないかは 分かりません。君の求めるコメントではないかもしれません。君が怒りを覚えるかもしれません。でも、私も 一人のムスリムとして、若き兄弟の為にと思い、コメントを書きます。君の人生の中で、いつか理解してもら える時がくると祈りながら、書きます。

生憎にも、クルアーンの正しさを身の回りの人に理解してもらおうと努力しても理解してもらえません。そ れは私が心からクルアーンが正しいと思い、真実であると思っても、そうなのです。ひろきくんの努力と導き により、現実世界では見えない精神世界での山谷を超えてきたその道のりがひろきくんをイスラムへ導き、そ して、改宗に至ったこと。それはひろきくんにしか見えない道のりなのです。同じ空気を吸って、同じ場所に いる家族でも、その家族一人一人の道のりはひろきくんの道のりではないのです。ひろきくんを含め先人の多 くのムスリム同胞たちはイスラムこそ真実と訴えかけます。しかし、理解してもらえません。それは私たちの 努力が足りないからなのか? と苦悩してしまいます。しかし、イスラムを理解するには、物理世界もしくは精 神世界の山谷道やいばらの道を歩き、気づくことが必要になります。多くの人は、「私は相手よりも優れてい る」という感覚を持つことで、心のゆとりを得ます。つまり、それは、「知らないことを知っているとするこ と」です。これは、イスラムではしてはいけないことなのです。それは周りに生えている木になった実を取る ようなことです。彼らは、その木のもとは種であったこと、そして、そのタネが地面と接し、発芽したことを 知りません。そして、双葉が芽生え、弱い木だった時を知りません。そして、長年の風雪と暑さ寒さに耐え、 初めて、実を結んだことを知りません。ここでは科学的木の成長過程を話しているのではなく、タネが腐らず に地面に寝付けた奇跡、そして、発芽した後誰にも踏まれず、痛まず、双葉が芽生えたという奇跡、日照条件 や土の状況、季節や雨量やよしわるしはあれども、成長し、初めての果実を実らせることができるほど成長し た奇跡。そんな億千万もの奇跡が重なって初めて、実りにたどり着けるのです。どれ一つとして損なってはい けないのです。その過程の美しさは何者にも変えられません。まさにその過程すべてにおいて、アッラーの慈 悲をなくしては実を結ばないのです。さて、実を取った人はその長年にわたる経緯に尊敬と感謝の念を抱きな がら、もぎったのでしょうか?答えは、「そこに実がなっており、美味しそうだったから。」という自らの欲か らくるものなのです。本題に戻ると、「自らの欲で動くとその過程や苦労が見えず、その力や能力があたかも 昔から備わっている」ように思ってしまうのです。そんな人に理解させようと思っても、それはその人が努力 をしなくてはなりません。果実の話をしましたが、ひろきくんの分かる範囲で話をしましょう。私たちは万有 引力の法則（ものは上から下へと落ちる。）という理論は生まれてから存在しており、当たり前だと感じてい ます。上記でいうと「その力や能力があたかも昔から備わっている」なのです。だから、私たちはそれを「常 識」と呼び、または「当たり前」だと呼びます。しかし、これを見つけたアイザック・ニュートンはどうでしょ う? 彼の人生と苦労そして、彼に対する支離滅裂な誹謗中傷があったことを私たちは知りません。まるで、彼 の考え方は発表後、すぐに認められ、科学の第一人者となったように書かれています。そして、アインシュタ 
インも例外ではありません。彼の理論が理解されなければ、彼は冴えない変な気の狂ったおじさんで終わると ころだったのです。今となれば、アインシュタインの名は誰もが知っています。しかし、私たちはアインシュ タイン、ニュートンを科学の父や物理の父と呼び、まるで、理論ができた時からすぐに認められたというょう な印象を持ってしまっています。実は彼らは壮絶な人生を過ごしているにもかかわらず、その過去は消され、 その理論を生み出した人の育ったわが国は素晴らしいと自国を讃えることに利用されてしまっているのです。

さて、そんな世の中でいかにクルアーンが正しいと説明できるでしょうか?

次に、以前にタフシールについて話していたね。タフシールはクルアーンの解説書であり、みんなが理解で きる最高のタフシールがあれば、クルアーンが真実だと証明できるという君のもつ意見を持っていたね。で も、タフシールはイスラム世界でイスラムについて学んだ人ならば、常識として知られています。しかし、よ く考えて欲しいところがあります。それって、私たちが学校で理科の授業で「万有引力の法則」を「常識」と いう知識として学ぶことと同じではないかと。つまり、イスラム圈で育った子供たちはイスラムが「(その力 や能力が）あたかも昔からあった」という状態に置かれてしまうのです。そこに私たちのような改宗者と生ま れながらのムスリムとの違いです。生まれながらのムスリムが改宗者を羡む点は、ムハンマドと同じとは言え ないが、それに匹敵しそうな「苦労をし、精神世界でいばらの道を歩いている」というまさに、ムハンマドが イスラムを見つけた時のように、アインシュタインがあの法則を見つけたように、そして、ニュートンが万有 引力の法則を見つけるような非常に名誉な時に巡り合えているのです。つまり、精神世界での苦労と努力をな し得た姿に彼らは賞賛を送ってくれています。生まれながらのムスリムは生憎にもクルアーンはタフシールの 檻に納められたただの書物になっているのかもしれません。本来はクルアーンと心を繋げ、クルアーンを現実 世界の下にある精神世界での指針として、利用できることが大切なのです。しかし、クルアーンはタフシール という檻の中です。極論を言えば、クルアーンが正しいと言える最高のタフシールがあるならば、それは、こ れまで生きていきたその人の人生を精神世界まで落とし込み、そして、理解できるかどうかです。それゆえ に、人生における経験は人によって異なってしまいます。

私たち日本人が日本人に対してダーワをする際、みんながうなづく「常識」や「当たり前」と思えるような タフシールが存在すれば、クルアーンの真実性は証明できます。しかし、「常識」や「当たり前」は「その力や 能力があたかも昔から備わっている」という解採となり、最終結論ばかりを求めてしまいがちになります。し かし、イスラムが本来教えたいのは「苦労やいばらの道を進むこと、そして、その過程の大切さ。」なのです。 なんと歯がゆい事態でしょう。私たちムスリムを救い、より多くのムスリムが生まれることを祈ります。

\section{References}

[1] 田原裕基. 規範倫理学における公理について. viXra preprint, 1908.0553, 2019.

[2] 田原裕基. 1 期間 2 項モデルを活用した失業保険の価格決定. viXra preprint, 1909.0302, 2019.

[3] Horiuchi Daiki; Tahara Hiroki. Note to Prove the Quranic Correctness II. OSF Preprints, b98nh, 2019. doi:10.31219/osf.io/b98nh

[4] TAHARA, Hiroki. The Mathematical Expressions of Quranic Exegeses and the Mathematical Definition of the Quranic Correctness. OSF Preprints, 6dsxb, 2019.

[5] TAHARA, Hiroki. Methodology to Prove the Quranic Correctness. International Journal of Humanities and Social Science Invention, 2019, 8.(10:1): 01-02.

[6] TAHARA, Hiroki. A Brainstorming of the Quranic Studies Inspired by the Evaluation of Coefficients of Polynomials. OSF Preprints, 6n9p3, 2019. 